\title{
Env-Specific Antibodies in Chronic Infection versus in Vaccination
}

\author{
Martina Soldemo and Gunilla B. Karlsson Hedestam* \\ Department of Microbiology, Tumor and Cell Biology, Karolinska Institutet, Stockholm, Sweden
}

OPEN ACCESS

Edited by:

Gabriella Scarlatti,

San Raffaele Hospital

(IRCCS), Italy

Reviewed by:

Stephen Kent,

University of Melbourne,

Australia

Egidio Brocca Cofano,

University of Pittsburgh,

United States

*Correspondence:

Gunilla B. Karlsson Hedestam gunilla.karlsson.hedestam@ki.se

Specialty section:

This article was submitted to HIV and AIDS,

a section of the journal

Frontiers in Immunology

Received: 10 July 2017

Accepted: 15 August 2017

Published: 04 September 2017

Citation:

Soldemo M and

Karlsson Hedestam GB (2017)

Env-Specific Antibodies in Chronic Infection versus in Vaccination.

Front. Immunol. 8:1057. doi: 10.3389/fimmu.2017.01057
Antibodies are central in vaccine-mediated protection. For HIV-1, a pathogen that displays extreme antigenic variability, B cell responses against conserved determinants of the envelope glycoproteins (Env) are likely required to achieve broadly protective vaccine-induced responses. To understand antibodies in chronic infection, where broad serum neutralizing activity is observed in a subset of individuals, monoclonal antibodies mediating this activity have been isolated. Studies of their maturation pathways reveal that years of co-evolution between the virus and the adaptive immune response are required for such responses to arise. Furthermore, they do so in subjects who display alterations of their B cell subsets caused by the chronic infection, conditions that are distinctly different from those in healthy hosts. So far, broadly neutralizing antibody responses were not induced by vaccination in primates or small animals with natural B cell repertoires. An increased focus on the development vaccine-induced responses in healthy subjects is therefore needed to delineate how the immune system recognizes different forms of HIV-1 Env and to optimize approaches to stimulate antibody responses against relevant neutralizing antibody epitopes. In this review, we describe aspects of Env-directed antibody responses that differ between chronic HIV-1 infection and subunit vaccination for an increased appreciation of these differences; and we highlight the need for an improved understanding of vaccine-induced B cell responses to complex glycoproteins such as Env, in healthy subjects.

\section{Keywords: B cells, HIV-1, neutralizing antibodies, vaccine, HIV-1 Infection}

\section{B CELL SUBSETS IN NORMAL PHYSIOLOGY}

The human adaptive immune system relies on several B-lymphocyte subsets with distinct roles. Circulating B cells can be classified as antigen-inexperienced or antigen-experienced cells. Among the former are the immature, transitional $\mathrm{B}$ cells and the mature naive $\mathrm{B}$ cells. Human transitional B cells are divided into T1 $\left(\mathrm{CD} 10^{+} \mathrm{CD} 21^{\mathrm{lo}} \mathrm{CD} 27^{-}\right)$and $\mathrm{T} 2 / 3\left(\mathrm{CD} 10^{+} \mathrm{CD} 21^{\mathrm{hi}} \mathrm{CD} 27^{-}\right)$ $B$ cells, while the mature naive $B$ cells are defined as $\mathrm{CD} 10^{-} \mathrm{CD} 20^{\text {hi }} \mathrm{CD} 27^{-}$cells. Transitional B cells and mature naive $B$ cells express germline-encoded immunoglobulin (Ig) genes of the $\operatorname{IgD}$ and/or IgM isotypes. In contrast, memory B cells, plasmablasts, and plasma cells are antigen-experienced cells that in most cases originate from germinal center reactions. Most antigen-experienced B cells have undergone somatic hypermutation (SHM) and class switch recombination to IgG, IgA, or IgE (1), but non-switched memory B cells also exist (2). Resting memory B cells persist by self-renewal, which proliferate and differentiate into plasma cells upon antigen re-exposure. To maintain the lineage following activation, some daughter cells remain as slowly dividing memory B cells, while others become terminally differentiated antibody-secreting cells (ASCs). Whether this is a stochastic process (3) or mediated by directed asymmetric cell division (4) 
remains a question of debate. Peripheral ASCs, often referred to as plasmablasts, are short-lived and distinct from the long-lived plasma cells found in bone marrow $(\mathrm{BM})$ or other anatomical niches that support their survival $(5,6)$.

During late-stage B cell development, immature/transitional $\mathrm{B}$ cells exit the BM to enter the circulation where they are subjected to peripheral selection. This is at least in part regulated by $\mathrm{B}$ cell-activating factor (BAFF), which is present in limited quantities, thereby setting a competitive threshold for B cell survival $(7,8)$. The surviving mature naive $B$ cells migrate to secondary lymphoid organs, i.e., the spleen, lymph nodes, and mucosa-associated lymphoid tissue. Upon antigen encounter, extrafollicular plasma cell responses resulting in the production of antibodies that have not undergone SHM may occur. However, most $\mathrm{B}$ cell responses against protein antigens are $\mathrm{T}$ cell dependent and products of germinal center reactions. Here, antigenspecific B cells undergo hypermutation of the encoded antibody sequences to diversify the antigen-specific repertoire and the resulting B cells interact closely with follicular dendritic cells and follicular helper $\mathrm{T}$ (Tfh) cells for selection of high affinity B cell clones. The signals that dictate $\mathrm{B}$ cell differentiation into memory $\mathrm{B}$ cells or plasma cells in the germinal center reaction are only beginning to be understood (9), including the important roles of Tfh cells (10-12). These processes are of high relevance for vaccine research as both memory $\mathrm{B}$ cells and plasma cells are needed for sustained humoral immunity.

\section{B CELL DYSFUNCTION IN HIV-1-INFECTED INDIVIDUALS}

During chronic HIV-1 infection, several imbalances in B cell subsets develop (Figure 1), affecting the capacity of chronically infected individuals to respond to vaccination and handle co-infections (13-17). Hypergammaglobulinemia and loss of B cell memory are hallmarks of these humoral immunity alterations $(18,19)$. Dysregulation of B cells is apparent relatively early after HIV-1 infection and worsens during disease progression. Early introduction of antiretroviral therapy to dampen active viremia has positive effects on preserving B cell subsets (20). Dysregulated B cell subsets and functions are also observed in individuals repeatedly exposed to malaria (19). Thus, B cell alterations in both HIV-1- and malaria-infected subjects are likely consequences of prolonged inflammatory responses that occur under these conditions, rather than caused by direct pathogen-B cell interactions. The specific B cell alterations described in chronically HIV-1-infected individuals include effects on both antigen-inexperienced cells and antigenexperienced cells as discussed below.

\section{Antigen-Inexperienced Cells}

HIV-1-infected individuals display increased frequencies of circulating immature transitional B cells (21). As transitional B cells display increased sensitivity to spontaneous apoptosis, this may lead to a decreased pool of mature naive $B$ cells $(22,23)$. Altered migratory capacity of immature transitional B cells was also observed, which could affect the distribution of these cells between blood and secondary lymphoid organs in HIV-1infected individuals (24). Furthermore, as mentioned earlier, peripheral B cell selection is regulated by BAFF, a B cell growth factor shown to be elevated in both chronic infection and autoimmunity $(25,26)$. BAFF is regulated by type I interferons (27); thus, increased BAFF levels in HIV-1 infection may result from sustained type I interferon responses due to chronic viremia. A potential consequence of increased BAFF levels is that B cell selection thresholds are altered, which may promote survival of B cells that otherwise would be subject to negative selection such as polyreactive or auto-reactive clonotypes $(28,29)$. Whether the naive B cell repertoire in HIV-1-infected individuals more frequently display features associated with poly- or self-reactivity is not known but will be important to investigate, especially in relation to the generation of broadly neutralizing antibodies (bNAbs) (30).

\section{Antigen-Experienced Cells}

HIV-1-infected individuals also display alterations of the memory $\mathrm{B}$ cell compartment. Activated human memory B cells, defined as $\mathrm{CD} 20^{+} / \mathrm{CD} 21^{\mathrm{lo}} / \mathrm{CD} 27^{+}$, and tissue-like memory B cells, defined as $\mathrm{CD} 20^{+} / \mathrm{CD} 21^{\mathrm{lo}} / \mathrm{CD} 27^{-}$, are increased during persistent $\mathrm{HIV}-1$ infection, whereas resting memory B cells, defined as $\mathrm{CD} 20^{+} /$ $\mathrm{CD} 21^{\mathrm{hi}} / \mathrm{CD} 27^{+}$, are decreased in frequency $(13,31)$. Consequences of these B cell compartment alterations are observed already

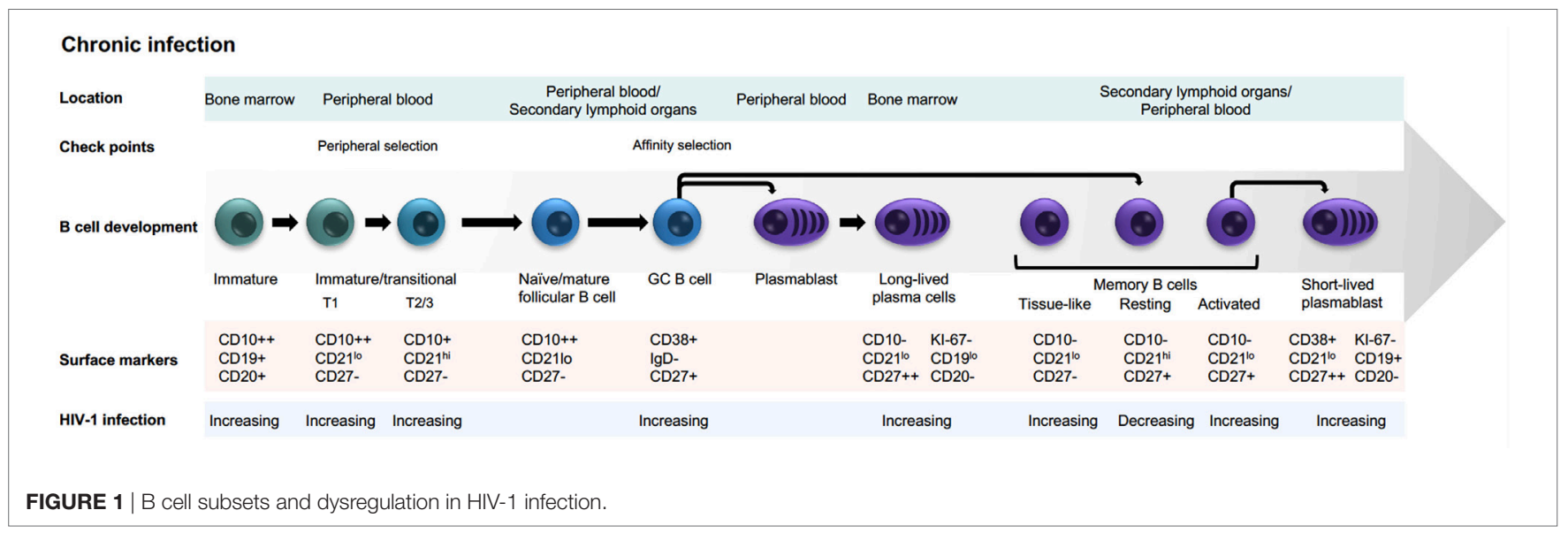


early in infection in the form of poor maintenance of serological antibody responses to previous vaccination (i.e., measles, tetanus, and pneumococcus) (17), as well as impaired responses to new vaccinations (32). During the chronic phase of the infection, exhausted B cells also appear. Exhausted B cells are characterized by a decreased capacity to proliferate in response to stimulation (33). The exhausted memory B cell phenotype is reminiscent of that of exhausted $\mathrm{T}$ cells with expression of molecules that negatively regulate antigen receptor signaling or homing to sites of inflammation $(34,35)$. Furthermore, HIV-1-infected individuals display increased frequencies of circulating CD20 ${ }^{-\prime}$ lo/CD27 ${ }^{\text {hi }} / \mathrm{CD} 38^{\text {hi }}$ plasmablasts (36) consistent with non-antigenspecific differentiation of memory B cells into ASCs resulting in hypergammaglobulinemia and decreased numbers of resting memory B cells. Thus, the immune system in chronically HIV-1infected individuals is different from that of healthy subjects in several ways, which likely affects the kinds of antibodies that are elicited. Below, we compare and contrast what is known about the induction of neutralizing antibody responses in chronic infection versus in immunization for an improved appreciation of these differences.

\section{THE Env TRIMER AS A NEUTRALIZING ANTIBODY TARGET}

The envelope glycoproteins of HIV-1 (Env) are the only virusencoded antigens exposed on the external surface of the virus particle and thus the sole targets for neutralizing antibodies. The HIV-1 Env spike is composed of a trimer of dimers in a tightly packed infectious entry unit where the external glycoprotein gp120 is non-covalently attached to the transmembrane protein gp41 $(37,38)$. The native HIV-1 Env trimer complex is meta-stable and readily acquires lower energy forms that are highly immunogenic [reviewed in Ref. (39)]. Antibodies elicited by these non-native forms of Env are non-neutralizing, or only capable of neutralizing sensitive (tier 1) viruses, which are distinctly different from circulating neutralization-resistant (tier 2) virus variants (38).

The functional Env spike is exceptionally well shielded from immune recognition by $\mathrm{N}$-linked glycans that cover most of the Env protein surface (40). The sites for N-linked glycosylation in the primary Env amino acid sequence vary between different virus strains and between different time points of viral evolution of a given strain demonstrating the plasticity of Env. HIV-1 evolves constantly in response to host antibody responses in each chronically infected individual, and neutralization-sensitive viruses are readily eliminated in vivo leaving only resistant variants in the circulating pool (41). An interesting recent study demonstrated that currently circulating HIV-1 variants are more neutralization resistant than variants isolated from the beginning of the epidemic, in part due to the acquisition of a denser Env glycan shield over time (42). The intrinsic neutralization resistance of $\mathrm{HIV}-1$ is a major challenge for vaccine development where the goal is to induce antibodies capable of neutralizing a broad range of tier 2 isolates to curb HIV-1 transmissions worldwide.

\section{Neutralizing Antibodies Elicited by Chronic Infection}

Env-specific antibodies generated during the first months of HIV-1 infection are non-neutralizing or strain-specific neutralizing. Non-neutralizing antibodies are elicited by highly immunogenic non-functional forms of Env as mentioned earlier. Strain-specific antibodies neutralize the autologous virus that elicited them but not contemporary viruses that arose subsequently as a result of immune escape from the first wave of antibodies (41). About 2-4 years after the acute of infection, approximately $20 \%$ of infected individuals develop cross-neutralizing antibodies (Figure 2) and 1-2\% of infected individuals develop bNAbs, which exhibit exceptionally potent neutralizing capacity against a large proportion of virus isolates $(43,44)$. Isolation and mapping of bNAbs at the monoclonal antibody level allows definition of their target epitopes, revealing sites of vulnerability on the virus that can be targeted by epitope-focused vaccine approaches (45-52).

Since chronic HIV-1 infection is characterized by an arms race between viral evolution and the adaptive immune response, new epitopes are continuously generated, sequentially driving the $\mathrm{B}$ cell repertoire toward the generation of bNAbs (53-55). The extensive antigenic variability in Env results mainly from the error-prone HIV-1 reverse transcriptase, which generates swarms of variants in each infectious cycle from which immune escape variants are selected. Despite the high antigenic variability of HIV-1 Env, some determinants are conserved as mutations in these elements compromise viral fitness. These regions are targets for bNAbs and include the primary receptor binding site, the CD4bs, certain variable region 2 (V2) determinants in the trimer apex, the base of the V 3 region, and the gp120-gp41 interface region [reviewed in Ref. (56)]. In the case of bNAbs targeting the V3 base, the surrounding N-glycans are often part of the epitope $(57,58)$. The glycan reactivity observed in many HIV-1-infected individuals (59) is intriguing since antibodies against $\mathrm{N}$-linked glycans is essentially a response against self-structures, which is uncommon in healthy subjects. Thus, the development of such antibodies in chronic HIV-1 infection may reflect a relaxation of peripheral check-points allowing potentially self-reactive $\mathrm{B}$ cells to escape negative selection (60).

Several studies have shown that bNAbs possess a high degree of divergence from their corresponding germline antibody sequences, indicating extensive SHM of the antibody sequences $(57,58,61)$. High SHM suggests that multiple rounds of affinity maturation and selection in germinal centers have occurred, which appears to be required to develop features associated with broad HIV-1 neutralization. High levels of SHM are not unique to bNAbs but are generally seen in HIV-1 infection (62), as well as in other chronic infections and some settings of autoimmunity (63). This suggests that extensive SHM is a consequence of prolonged antigen exposure and persistent inflammatory responses, processes that allow selection of $\mathrm{B}$ cells over long periods of time. However, it is likely that not all changes introduced by SHM are required for bNAb activity as shown for the bNAb VRC01, where a subset of the amino acid changes that differed between the 


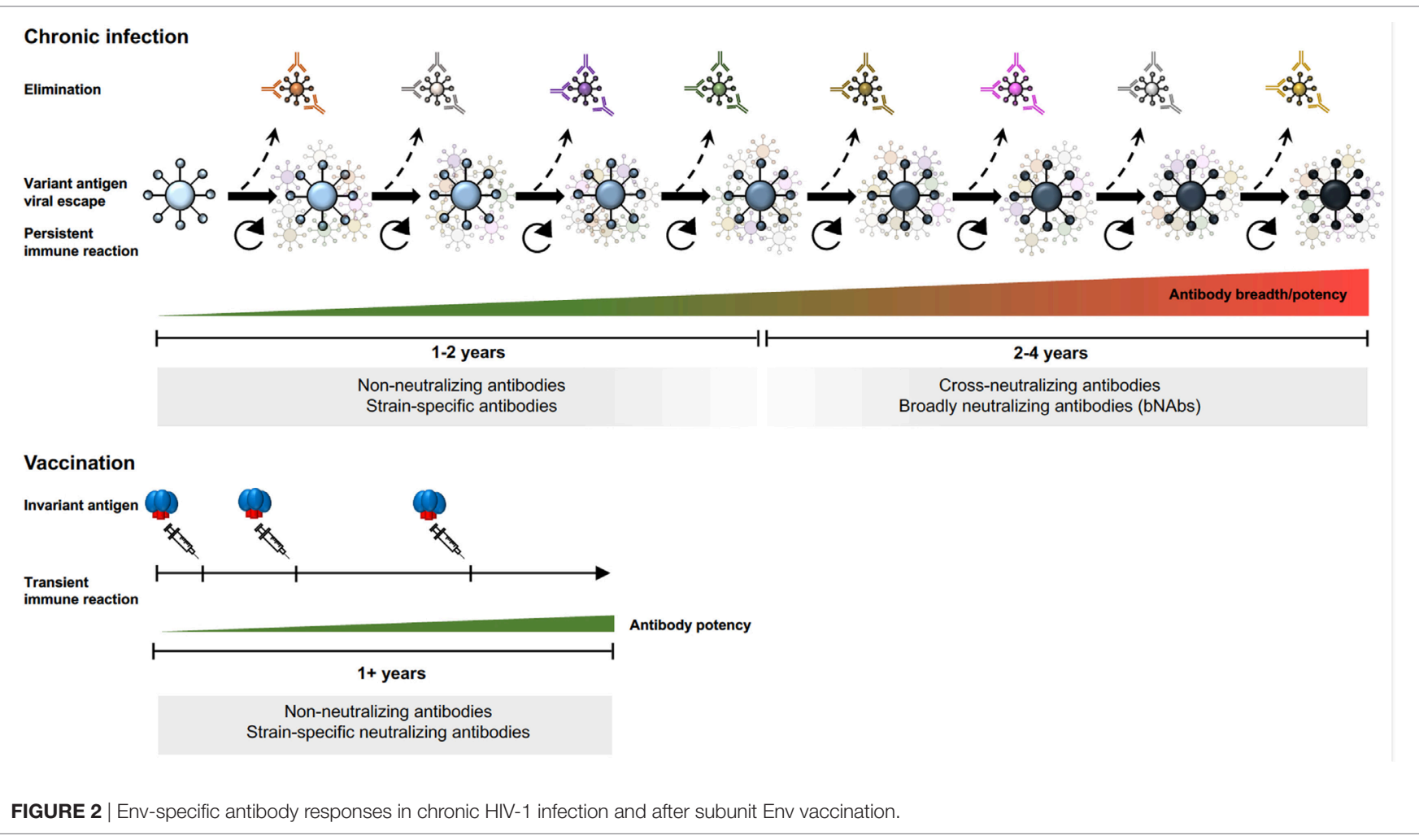

mature antibody and the assigned germline VH1-2*02 sequence were sufficient to confer bNAb activity (64).

The high degree of divergence of bNAb sequences from their germline Ig gene segments complicates the process of inferring the unmutated recombined ancestor sequences for these antibodies. Studies of germline-reverted bNAb sequences have shown that they rarely bind Env suggesting that they possess very low initial affinities to the unmutated BCR (65). However, in most cases where this was studied, the Env present in the patient at the time of elicitation of the bNAb lineage was not known. An exception to this is the identification of antibody $\mathrm{CH} 103$, which binds the presumed transmitted/founder Env in its germlinereverted form (55). The lack of Env binding to germline-reverted bNAbs may be explained by the fact that some human germline variable (V) alleles are missing in the current databases, which could affect the processes of germline reversion (66). In support of this, it is becoming increasingly clear that there are more human antibody $\mathrm{V}$ alleles than previously appreciated (67-70). An improved understanding of human antibody germline genes is therefore needed. We recently reported that next-generation sequencing (NGS) coupled with a new computational tool, IgDiscover, can accelerate the definition of germline-encoded Ig gene segments and allow higher-throughput studies (70).

HIV-1 bNAb sequences stand out not only because of high levels of divergence from their germline sequences in terms of single nucleotide differences but also because they frequently display insertions and deletions (indels) introduced during the process of SHM (71). Indels, which are rarely seen in antibodies elicited in healthy subjects, generate further diversity in infection-induced Env-specific antibody repertoires, an area that is only beginning to be understood. The present increase in NGS-based antibody repertoire analysis provides highly valuable information about how the human $\mathrm{B}$ cell response evolves during chronic infections. Another characteristic feature of some classes of HIV-1 bNAbs, such as the apextargeting antibodies, is their exceptionally long heavy chain complementarity-determining region 3 sequences. $B$ cells encoding BCRs with such long HCDRs are rare in the naive B cell population but appear to be preferentially selected in Envspecific responses, at least in a subset of individuals. This feature is likely required for the antibodies to penetrate the dense glycan shield and bind conserved determinants at the Env trimer apex $(72,73)$. Collectively, these genetic features demonstrate that HIV-1 antibodies are highly selected and bNAb specificities arise from extensive co-evolution processes between the virus and responding $\mathrm{B}$ cells.

\section{Neutralizing Antibodies Elicited by Subunit Env Vaccination}

The persistent B cell selection observed during chronic HIV-1 infection is in stark contrast to the transient response that takes place following vaccination with non-replicating subunit vaccines. Highly mutated antibodies are not induced by current immunization regimens but might be achievable by using heterologous Env immunogens administered in a sequential manner to promote responses to common determinants on HIV-1 Env. So far, bNAbs have not been elicited by immunization of primates with natural 
immune repertoires. Given that bNAb development in infection depends on extensive B cell selection on a constantly changing pool of virus escape variants, it is not surprising that conventional immunization regimens do not induce bNAb specificities. It is also not known if certain precursor populations are lost during peripheral $\mathrm{B}$ cell selection processes, which are known to be under tighter control in healthy vaccine recipients than in chronically infected HIV-1 individuals as mentioned earlier.

Immunization studies using early generation Env trimers provided valuable information about the $\mathrm{B}$ cell response elicited in both small animals and in primates. While tier 1-neutralizing antibody responses are readily induced, tier 2-neutralizing responses are mostly limited to autologous tier 2 responses (Figure 2) (74, 75). For a detailed understanding of epitopespecific antibody responses induced by vaccination, methods for antibody specificity mapping and isolation of monoclonal antibodies are needed. Such methodologies are under continuous development to facilitate analyses of vaccine-induced responses at a higher level of resolution [reviewed in (76)]. Results from immunized non-human primates demonstrate that Env vaccine-induced responses consist of many different clonotypes, most of which appear to be modestly expanded (77-79). Highly polyclonal B cell responses are also observed in humans vaccinated with tetanus toxoid, another protein subunit-based vaccine, administered using a homologous prime-boost regimen $(80,81)$. It is perhaps not surprising that vaccine regimens based on homologous boosting result in polyclonal B cell responses with modest levels of SHM where each clonotype has reached an affinity ceiling to the invariant vaccine antigen (82), rather than being driven by a constantly changing antigen that repeatedly resets the affinity threshold for $B$ cell selection, as is the case in HIV-1 infection.

Despite the many contrasts between chronic infection and vaccination, dissection of Env vaccine-induced antibody responses at the monoclonal level has also revealed similarities in terms of the targeted epitopes. For example, antibodies against non-neutralizing epitopes in gp41 as well as against tier 1-neutralizing epitopes in variable region 3 (V3) are readily elicited in both settings suggesting that these specificities are abundant in the naive B cell repertoire in both humans and commonly used animal models as shown by monoclonal antibody isolation $(78,83,84)$. Similarly, CD4bs-directed antibodies capable of neutralizing tier 1 viruses, exemplified by the non-broad neutralizing antibody F105, are elicited both in infection (85) and in vaccination of non-human primates (86). The availability of protocols for efficient cloning of antibodies from non-human primates $(86,87)$ has facilitated such studies and are now widely used to dissect vaccine-induced responses in rhesus macaques. With the exception of one study (88), less is known about

\section{REFERENCES}

1. McHeyzer-Williams M, Okitsu S, Wang N, McHeyzer-Williams L. Molecular programming of B cell memory. Nat Rev Immunol (2011) 12(1):24-34. doi: $10.1038 /$ nri3128

2. Taylor JJ, Pape KA, Jenkins MK. A germinal center-independent pathway generates unswitched memory B cells early in the primary response. J Exp Med (2012) 209(3):597-606. doi:10.1084/jem.20111696 epitope-specific antibody responses in immunized rabbits where germline Ig genes so far are insufficiently characterized, currently hampering monoclonal antibody isolation in this model.

While early generation HIV-1 Env vaccine candidates were poor mimics of the functional Env spike, recent work has resulted in immunogens that better mimic the native viral spike. The definition of a native spike structure is that bNAbs epitopes are retained while non-neutralizing $\mathrm{Ab}$ epitopes are not. Soluble trimeric Env immunogens that meet these criteria include the BG505 SOSIP trimers and the Native Flexibly Linked (NFL trimers) (89-91) for which high-resolution structures were obtained (92-94). Emerging in vivo evaluation of the immunogenicity of these trimers, when used in homologous prime-boost regimens, demonstrates that they elicit autologous tier 2-neutralizing antibody responses but limited neutralization breadth (95). The epitopes mediating strain-specific neutralization may be different for different HIV-1 strains, or in different host species, as exemplified by the finding that antibodies against the V2 region mediate the autologous neutralizing activity induced by clade C 16055 trimers in NHPs (95), while antibodies against the gp120-gp41 interface mediate the autologous neutralizing activity induced by clade A BG505 trimers in rabbits (88). The role played by potential differences in host $B$ cell repertoires in terms of the specificities induced by a given immunogen remains insufficiently understood but will be important to determine to better understand predictability of different animal models for assessment of human vaccine candidates. In this respect, it was shown the same immunogen that elicits potent autologous neutralizing antibodies in rabbits fails to do so in mice (96). Further work is required to define similarities and differences in germline antibody genes and expressed repertoires between commonly used animal models, including small animals, NHPs, and humans.

In conclusion, while much has been learnt from studying the development of bNAbs in chronic HIV-1 infection, focused efforts are now needed to translate these findings to the setting of vaccination. Given the challenge of this goal, achieving this will require coordinated vaccine evaluation trials in both well-chosen animal models and in humans.

\section{AUTHOR CONTRIBUTIONS}

MS created the figures. MS and GKH jointly wrote the manuscript.

\section{ACKNOWLEDGMENTS}

This work was supported by a grant from the Swedish Research Council and an European AIDS Vaccine Initiative (EAVI) 2020 (681137) grant. The authors thank Dr. Paola Martinez-Murillo for proofreading the manuscript.

3. Duffy KR, Wellard CJ, Markham JF, Zhou JH, Holmberg R, Hawkins ED, et al. Activation-induced B cell fates are selected by intracellular stochastic competition. Science (2012) 335(6066):338-41. doi:10.1126/science. 1213230

4. Lin WH, Adams WC, Nish SA, Chen YH, Yen B, Rothman NJ, et al. Asymmetric PI3K signaling driving developmental and regenerative cell fate bifurcation. Cell Rep (2015) 13(10):2203-18. doi:10.1016/j.celrep.2015. 10.072 
5. Ellyard JI, Avery DT, Phan TG, Hare NJ, Hodgkin PD, Tangye SG. Antigen-selected, immunoglobulin-secreting cells persist in human spleen and bone marrow. Blood (2004) 103(10):3805-12. doi:10.1182/blood-200309-3109

6. Landsverk OJ, Snir O, Casado RB, Richter L, Mold JE, Réu P, et al. Antibody-secreting plasma cells persist for decades in human intestine. J Exp Med (2017) 214(2):309-17. doi:10.1084/jem.20161590

7. Batten M, Groom J, Cachero TG, Qian F, Schneider P, Tschopp J, et al. BAFF mediates survival of peripheral immature B lymphocytes. J Exp Med (2000) 192(10):1453-66. doi:10.1084/jem.192.10.1453

8. Ota M, Duong BH, Torkamani A, Doyle CM, Gavin AL, Ota T, et al. Regulation of the B cell receptor repertoire and self-reactivity by BAFF. J Immunol (2010) 185(7):4128-36. doi:10.4049/jimmunol.1002176

9. Weisel FJ, Zuccarino-Catania GV, Chikina M, Shlomchik MJ. A temporal switch in the germinal center determines differential output of memory B and plasma cells. Immunity (2016) 44(1):116-30. doi:10.1016/j.immuni. 2015.12.004

10. Havenar-Daughton C, Carnathan DG, Torrents de la Peña A, Pauthner M, Briney B, Reiss SM, et al. Direct probing of germinal center responses reveals immunological features and bottlenecks for neutralizing antibody responses to HIV Env Trimer. Cell Rep (2016) 17(9):2195-209. doi:10.1016/j. celrep.2016.10.085

11. Linterman MA, Beaton L, Yu D, Ramiscal RR, Srivastava M, Hogan JJ, et al. IL-21 acts directly on B cells to regulate Bcl-6 expression and germinal center responses. J Exp Med (2010) 207(2):353-63. doi:10.1084/jem. 20091738

12. Wang Y, Shi J, Yan J, Xiao Z, Hou X, Lu P, et al. Germinal-center development of memory B cells driven by IL-9 from follicular helper T cells. Nat Immunol (2017) 18(8):921-30. doi:10.1038/ni.3788

13. Amu S, Ruffin N, Rethi B, Chiodi F. Impairment of B-cell functions during HIV-1 infection. AIDS (2013) 27(15):2323-34. doi:10.1097/QAD. 0b013e328361a427

14. Cagigi A, Nilsson A, Pensieroso S, Chiodi F. Dysfunctional B-cell responses during HIV-1 infection: implication for influenza vaccination and highly active antiretroviral therapy. Lancet Infect Dis (2010) 10(7):499-503. doi:10.1016/S1473-3099(10)70117-1

15. Moir S, Fauci AS. B cells in HIV infection and disease. Nat Rev Immunol (2009) 9(4):235-45. doi:10.1038/nri2524

16. Moir S, Malaspina A, Ogwaro KM, Donoghue ET, Hallahan CW, Ehler LA, et al. HIV-1 induces phenotypic and functional perturbations of B cells in chronically infected individuals. Proc Natl Acad Sci U S A (2001) 98(18):10362-7. doi:10.1073/pnas.181347898

17. Titanji K, De Milito A, Cagigi A, Thorstensson R, Grützmeier S, Atlas A, et al. Loss of memory B cells impairs maintenance of long-term serologic memory during HIV-1 infection. Blood (2006) 108(5):1580-7. doi:10.1182/ blood-2005-11-013383

18. Lane HC, Masur H, Edgar LC, Whalen G, Rook AH, Fauci AS. Abnormalities of B-cell activation and immunoregulation in patients with the acquired immunodeficiency syndrome. NEngl J Med (1983) 309(8):453-8. doi:10.1056/ NEJM198308253090803

19. Illingworth J, Butler NS, Roetynck S, Mwacharo J, Pierce SK, Bejon P, et al. Chronic exposure to Plasmodium falciparum is associated with phenotypic evidence of B and T cell exhaustion. J Immunol (2013) 190(3):1038-47. doi:10.4049/jimmunol.1202438

20. Titanji K, Chiodi F, Bellocco R, Schepis D, Osorio L, Tassandin C, et al. Primary HIV-1 infection sets the stage for important B lymphocyte dysfunctions. AIDS (2005) 19(17):1947-55. doi:10.1097/01.aids.0000191231.54170.89

21. Malaspina A, Moir S, Ho J, Wang W, Howell ML, O'Shea MA, et al. Appearance of immature/transitional B cells in HIV-infected individuals with advanced disease: correlation with increased IL-7. Proc Natl Acad Sci U S A (2006) 103(7):2262-7. doi:10.1073/pnas.0511094103

22. Ho J, Moir S, Malaspina A, Howell ML, Wang W, DiPoto AC, et al. Two overrepresented B cell populations in HIV-infected individuals undergo apoptosis by different mechanisms. Proc Natl Acad Sci U S A (2006) 103(51):19436-41. doi:10.1073/pnas.0609515103

23. Lundstrom W, Fewkes NM, Mackall CL. IL-7 in human health and disease. Semin Immunol (2012) 24(3):218-24. doi:10.1016/j.smim.2012.02.005

24. Amu S, Fievez V, Nozza S, Lopalco L, Chiodi F. Dysfunctions in the migratory phenotype and properties of circulating immature transitional
B cells during HIV-1 infection. AIDS (2016) 30(14):2169-77. doi:10.1097/ QAD.0000000000001182

25. Rodriguez B, Valdez H, Freimuth W, Butler T, Asaad R, Lederman MM. Plasma levels of B-lymphocyte stimulator increase with HIV disease progression. AIDS (2003) 17(13):1983-5. doi:10.1097/00002030-20030905000018

26. Groom J, Kalled SL, Cutler AH, Olson C, Woodcock SA, Schneider P, et al. Association of BAFF/BLyS overexpression and altered B cell differentiation with Sjogren's syndrome. JClin Invest (2002) 109(1):59-68. doi:10.1172/ JCI0214121

27. Gomez AM, Ouellet M, Tremblay MJ. HIV-1-triggered release of type I IFN by plasmacytoid dendritic cells induces BAFF production in monocytes. J Immunol (2015) 194(5):2300-8. doi:10.4049/jimmunol.1402147

28. Gross JA, Johnston J, Mudri S, Enselman R, Dillon SR, Madden K, et al. TACI and BCMA are receptors for a TNF homologue implicated in B-cell autoimmune disease. Nature (2000) 404(6781):995-9. doi:10.1038/ 35010115

29. Mackay F, Woodcock SA, Lawton P, Ambrose C, Baetscher M, Schneider P, et al. Mice transgenic for BAFF develop lymphocytic disorders along with autoimmune manifestations. J Exp Med (1999) 190(11):1697-710. doi:10.1084/jem.190.11.1697

30. Yang G, Holl TM, Liu Y, Li Y, Lu X, Nicely NI, et al. Identification of autoantigens recognized by the $2 \mathrm{~F} 5$ and $4 \mathrm{E} 10$ broadly neutralizing HIV-1 antibodies. J Exp Med (2013) 210(2):241-56. doi:10.1084/jem.20121977

31. Moir S, Buckner CM, Ho J, Wang W, Chen J, Waldner AJ, et al. B cells in early and chronic HIV infection: evidence for preservation of immune function associated with early initiation of antiretroviral therapy. Blood (2010) 116(25):5571-9. doi:10.1182/blood-2010-05-285528

32. Hart M, Steel A, Clark SA, Moyle G, Nelson M, Henderson DC, et al. Loss of discrete memory B cell subsets is associated with impaired immunization responses in HIV-1 infection and may be a risk factor for invasive pneumococcal disease. JImmunol (2007) 178(12):8212-20. doi:10.4049/ jimmunol.178.12.8212

33. Moir S, Ho J, Malaspina A, Wang W, DiPoto AC, O'Shea MA, et al. Evidence for HIV-associated B cell exhaustion in a dysfunctional memory B cell compartment in HIV-infected viremic individuals. J Exp Med (2008) 205(8):1797-805. doi:10.1084/jem.20072683

34. Moir S, Fauci AS. B-cell exhaustion in HIV infection: the role of immune activation. Curr Opin HIV AIDS (2014) 9(5):472-7. doi:10.1097/ COH.0000000000000092

35. Moir S, Fauci AS. B-cell responses to HIV infection. Immunol Rev (2017) 275(1):33-48. doi:10.1111/imr.12502

36. Doria-Rose NA, Klein RM, Manion MM, O'Dell S, Phogat A, Chakrabarti B, et al. Frequency and phenotype of human immunodeficiency virus envelope-specific $B$ cells from patients with broadly cross-neutralizing antibodies. J Virol (2009) 83(1):188-99. doi:10.1128/JVI.01583-08

37. Wyatt R, Sodroski J. The HIV-1 envelope glycoproteins: fusogens, antigens, and immunogens. Science (1998) 280(5371):1884-8. doi:10.1126/ science.280.5371.1884

38. Seaman MS, Janes H, Hawkins N, Grandpre LE, Devoy C, Giri A, et al. Tiered categorization of a diverse panel of HIV-1 Env pseudoviruses for assessment of neutralizing antibodies. JVirol (2010) 84(3):1439-52. doi:10.1128/ JVI.02108-09

39. Burton DR, Mascola JR. Antibody responses to envelope glycoproteins in HIV-1 infection. Nat Immunol (2015) 16(6):571-6. doi:10.1038/ni.3158

40. Wei X, Decker JM, Wang S, Hui H, Kappes JC, Wu X, et al. Antibody neutralization and escape by HIV-1. Nature (2003) 422(6929):307-12. doi:10.1038/ nature 01470

41. Richman DD, Wrin T, Little SJ, Petropoulos CJ. Rapid evolution of the neutralizing antibody response to HIV type 1 infection. Proc Natl Acad Sci U S A (2003) 100(7):4144-9. doi:10.1073/pnas.0630530100

42. Bunnik EM, Euler Z, Welkers MR, Boeser-Nunnink BD, Grijsen ML, Prins JM, et al. Adaptation of HIV-1 envelope gp 120 to humoral immunity at a population level. Nat Med (2010) 16(9):995-7. doi:10.1038/nm.2203

43. Simek MD, Rida W, Priddy FH, Pung P, Carrow E, Laufer DS, et al. Human immunodeficiency virus type 1 elite neutralizers: individuals with broad and potent neutralizing activity identified by using a high-throughput neutralization assay together with an analytical selection algorithm. J Virol (2009) 83(14):7337-48. doi:10.1128/JVI.00110-09 
44. Doria-Rose NA, Klein RM, Daniels MG, O’Dell S, Nason M, Lapedes A, et al. Breadth of human immunodeficiency virus-specific neutralizing activity in sera: clustering analysis and association with clinical variables. J Virol (2010) 84(3):1631-6. doi:10.1128/JVI.01482-09

45. Huang J, Kang BH, Ishida E, Zhou T, Griesman T, Sheng Z, et al. Identification of a CD4-binding-site antibody to HIV that evolved near-pan neutralization breadth. Immunity (2016) 45(5):1108-21. doi:10.1016/j.immuni.2016. 10.027

46. Huang J, Ofek G, Laub L, Louder MK, Doria-Rose NA, Longo NS, et al. Broad and potent neutralization of HIV-1 by a gp41-specific human antibody. Nature (2012) 491(7424):406-12. doi:10.1038/nature11544

47. Kong R, Xu K, Zhou T, Acharya P, Lemmin T, Liu K, et al. Fusion peptide of HIV-1 as a site of vulnerability to neutralizing antibody. Science (2016) 352(6287):828-33. doi:10.1126/science.aae0474

48. Moldt B, Rakasz EG, Schultz N, Chan-Hui PY, Swiderek K, Weisgrau KL, et al. Highly potent HIV-specific antibody neutralization in vitro translates into effective protection against mucosal SHIV challenge in vivo. Proc Natl Acad Sci U S A (2012) 109(46):18921-5. doi:10.1073/pnas.1214785109

49. Zhou T, Georgiev I, Wu X, Yang ZY, Dai K, Finzi A, et al. Structural basis for broad and potent neutralization of HIV-1 by antibody VRC01. Science (2010) 329(5993):811-7. doi:10.1126/science.1192819

50. Mouquet H, Scharf L, Euler Z, Liu Y, Eden C, Scheid JF, et al. Complextype N-glycan recognition by potent broadly neutralizing HIV antibodies. Proc Natl Acad Sci U S A (2012) 109(47):E3268-77. doi:10.1073/pnas. 1217207109

51. Schoofs T, Klein F, Braunschweig M, Kreider EF, Feldmann A, Nogueira L, et al. HIV-1 therapy with monoclonal antibody 3BNC117 elicits host immune responses against HIV-1. Science (2016) 352(6288):997-1001. doi:10.1126/ science.aaf0972

52. Gristick HB, von Boehmer L, West AP Jr, Schamber M, Gazumyan A, Golijanin J, et al. Natively glycosylated HIV-1 Env structure reveals new mode for antibody recognition of the CD4-binding site. Nat Struct Mol Biol (2016) 23(10):906-15. doi:10.1038/nsmb.3291

53. Wibmer CK, Bhiman JN, Gray ES, Tumba N, Abdool Karim SS, Williamson C, et al. Viral escape from HIV-1 neutralizing antibodies drives increased plasma neutralization breadth through sequential recognition of multiple epitopes and immunotypes. PLoS Pathog (2013) 9(10):e1003738. doi:10.1371/journal.ppat.1003738

54. Doria-Rose NA, Schramm CA, Gorman J, Moore PL, Bhiman JN, DeKosky BJ, et al. Developmental pathway for potent V1V2-directed HIV-neutralizing antibodies. Nature (2014) 509(7498):55-62. doi:10.1038/ nature 13036

55. Liao HX, Lynch R, Zhou T, Gao F, Alam SM, Boyd SD, et al. Co-evolution of a broadly neutralizing HIV-1 antibody and founder virus. Nature (2013) 496(7446):469-76. doi:10.1038/nature12053

56. Kwong PD, Mascola JR, Nabel GJ. Broadly neutralizing antibodies and the search for an HIV-1 vaccine: the end of the beginning. Nat Rev Immunol (2013) 13(9):693-701. doi:10.1038/nri3516

57. Sok D, Doores KJ, Briney B, Le KM, Saye-Francisco KL, Ramos A, et al. Promiscuous glycan site recognition by antibodies to the high-mannose patch of gp120 broadens neutralization of HIV. Sci Transl Med (2014) 6(236):236ra63. doi:10.1126/scitranslmed.3008104

58. Garces F, Lee JH, de Val N, de la Pena AT, Kong L, Puchades C, et al. Affinity maturation of a potent family of HIV antibodies is primarily focused on accommodating or avoiding glycans. Immunity (2015) 43(6):1053-63. doi:10.1016/j.immuni.2015.11.007

59. Landais E, Huang X, Havenar-Daughton C, Murrell B, Price MA, Wickramasinghe $\mathrm{L}$, et al. Broadly neutralizing antibody responses in a large longitudinal sub-Saharan HIV primary infection cohort. PLoS Pathog (2016) 12(1):e1005369. doi:10.1371/journal.ppat.1005369

60. Verkoczy L, Kelsoe G, Moody MA, Haynes BF. Role of immune mechanisms in induction of HIV-1 broadly neutralizing antibodies. Curr Opin Immunol (2011) 23(3):383-90. doi:10.1016/j.coi.2011.04.003

61. Klein F, Diskin R, Scheid JF, Gaebler C, Mouquet H, Georgiev IS, et al. Somatic mutations of the immunoglobulin framework are generally required for broad and potent HIV-1 neutralization. Cell (2013) 153(1):126-38. doi:10.1016/j.cell.2013.03.018

62. Scheid JF, Mouquet H, Feldhahn N, Seaman MS, Velinzon K, Pietzsch J, et al. Broad diversity of neutralizing antibodies isolated from memory B cells in
HIV-infected individuals. Nature (2009) 458(7238):636-40. doi:10.1038/ nature 07930

63. Breden F, Lepik C, Longo NS, Montero M, Lipsky PE, Scott JK. Comparison of antibody repertoires produced by HIV-1 infection, other chronic and acute infections, and systemic autoimmune disease. PLoS One (2011) 6(3):e16857. doi:10.1371/journal.pone.0016857

64. Jardine JG, Sok D, Julien JP, Briney B, Sarkar A, Liang CH, et al. Minimally mutated HIV-1 broadly neutralizing antibodies to guide reductionist vaccine design. PLoS Pathog (2016) 12(8):e1005815. doi:10.1371/journal.ppat. 1005815

65. Xiao X, Chen W, Feng Y, Zhu Z, Prabakaran P, Wang Y, et al. Germline-like predecessors of broadly neutralizing antibodies lack measurable binding to HIV-1 envelope glycoproteins: implications for evasion of immune responses and design of vaccine immunogens. Biochem Biophys Res Commun (2009) 390(3):404-9. doi:10.1016/j.bbrc.2009.09.029

66. Gadala-Maria D, Yaari G, Uduman M, Kleinstein SH. Automated analysis of high-throughput B-cell sequencing data reveals a high frequency of novel immunoglobulin V gene segment alleles. Proc Natl Acad Sci U S A (2015) 112(8):E862-70. doi:10.1073/pnas.1417683112

67. Scheepers C, Shrestha RK, Lambson BE, Jackson KJ, Wright IA, Naicker D, et al. Ability to develop broadly neutralizing HIV-1 antibodies is not restricted by the germline Ig gene repertoire. JImmunol (2015) 194(9):4371-8. doi:10.4049/jimmunol.1500118

68. Watson CT, Glanville J, Marasco WA. The Individual and population genetics of antibody immunity. Trends Immunol (2017) 38(7):459-70. doi:10.1016/j. it.2017.04.003

69. Boyd SD, Gaëta BA, Jackson KJ, Fire AZ, Marshall EL, Merker JD, et al. Individual variation in the germline Ig gene repertoire inferred from variable region gene rearrangements. J Immunol (2010) 184(12):6986-92. doi:10.4049/ jimmunol.1000445

70. Corcoran MM, Phad GE, Vázquez Bernat N, Stahl-Hennig C, Sumida N, Persson MA, et al. Production of individualized V gene databases reveals high levels of immunoglobulin genetic diversity. Nat Commun (2016) 7:13642. doi: $10.1038 /$ ncomms 13642

71. Kepler TB, Liao HX, Alam SM, Bhaskarabhatla R, Zhang R, Yandava C, et al. Immunoglobulin gene insertions and deletions in the affinity maturation of HIV-1 broadly reactive neutralizing antibodies. Cell Host Microbe (2014) 16(3):304-13. doi:10.1016/j.chom.2014.08.006

72. Pejchal R, Walker LM, Stanfield RL, Phogat SK, Koff WC, Poignard P, et al. Structure and function of broadly reactive antibody PG16 reveal an H3 subdomain that mediates potent neutralization of HIV-1. Proc Natl Acad Sci U S A (2010) 107(25):11483-8. doi:10.1073/pnas.1004600107

73. Lee JH, Andrabi R, Su CY, Yasmeen A, Julien JP, Kong L, et al. A broadly neutralizing antibody targets the dynamic HIV envelope trimer apex via a long, rigidified, and anionic beta-hairpin structure. Immunity (2017) 46(4):690-702. doi:10.1016/j.immuni.2017.03.017

74. Martinez P, Sundling C, O’Dell S, Mascola JR, Wyatt RT, Karlsson Hedestam GB. Primate immune responses to HIV-1 Env formulated in the saponin-based adjuvant AbISCO-100 in the presence or absence of TLR9 co-stimulation. Sci Rep (2015) 5:8925. doi:10.1038/srep08925

75. Grundner C, Li Y, Louder M, Mascola J, Yang X, Sodroski J, et al. Analysis of the neutralizing antibody response elicited in rabbits by repeated inoculation with trimeric HIV-1 envelope glycoproteins. Virology (2005) 331(1):33-46. doi:10.1016/j.virol.2004.09.022

76. Karlsson Hedestam GB, Guenaga J, Corcoran M, Wyatt RT. Evolution of B cell analysis and Env trimer redesign. Immunol Rev (2017) 275(1):183-202. doi:10.1111/imr.12515

77. Sundling C, Zhang Z, Phad GE, Sheng Z, Wang Y, Mascola JR, et al. Singlecell and deep sequencing of IgG-switched macaque $B$ cells reveal a diverse Ig repertoire following immunization. JImmunol (2014) 192(8):3637-44. doi:10.4049/jimmunol.1303334

78. Phad GE, Vázquez Bernat N, Feng Y, Ingale J, Martinez Murillo PA, O’Dell S, et al. Diverse antibody genetic and recognition properties revealed following HIV-1 envelope glycoprotein immunization. J Immunol (2015) 194(12): 5903-14. doi:10.4049/jimmunol.1500122

79. Wang Y, Sundling C, Wilson R, O’Dell S, Chen Y, Dai K, et al. High-resolution longitudinal study of HIV-1 Env vaccine-elicited B cell responses to the virus primary receptor binding site reveals affinity maturation and clonal persistence. J Immunol (2016) 196(9):3729-43. doi:10.4049/jimmunol.1502543 
80. Poulsen TR, Meijer PJ, Jensen A, Nielsen LS, Andersen PS. Kinetic, affinity, and diversity limits of human polyclonal antibody responses against tetanus toxoid. J Immunol (2007) 179(6):3841-50. doi:10.4049/jimmunol.179.6.3841

81. Poulsen TR, Jensen A, Haurum JS, Andersen PS. Limits for antibody affinity maturation and repertoire diversification in hypervaccinated humans. J Immunol (2011) 187(8):4229-35. doi:10.4049/jimmunol.1000928

82. Foote J, Eisen HN. Kinetic and affinity limits on antibodies produced during immune responses. Proc Natl Acad Sci U S A (1995) 92(5):1254-6. doi:10.1073/ pnas.92.5.1254

83. Gnann JW Jr, Nelson JA, Oldstone MB. Fine mapping of an immunodominant domain in the transmembrane glycoprotein of human immunodeficiency virus. J Virol (1987) 61(8):2639-41.

84. Goudsmit J, Kuiken CL, Nara PL. Linear versus conformational variation of V3 neutralization domains of HIV-1 during experimental and natural infection. AIDS (1989) 3(Suppl 1):S119-23. doi:10.1097/00002030-19890100100017

85. Posner MR, Cavacini LA, Emes CL, Power J, Byrn R. Neutralization of HIV-1 by F105, a human monoclonal antibody to the CD4 binding site of gp120. J Acquir Immune Defic Syndr (1993) 6(1):7-14.

86. Sundling C, Li Y, Huynh N, Poulsen C, Wilson R, O’Dell S, et al. Highresolution definition of vaccine-elicited $\mathrm{B}$ cell responses against the HIV primary receptor binding site. Sci Transl Med (2012) 4(142):142ra96. doi:10.1126/scitranslmed.3003752

87. Sundling C, Phad G, Douagi I, Navis M, Karlsson Hedestam GB. Isolation of antibody $\mathrm{V}(\mathrm{D}) \mathrm{J}$ sequences from single cell sorted rhesus macaque B cells. J Immunol Methods (2012) 386(1-2):85-93. doi:10.1016/j.jim.2012.09.003

88. McCoy LE, van Gils MJ, Ozorowski G, Messmer T, Briney B, Voss JE, et al. Holes in the glycan shield of the native HIV envelope are a target of trimer-elicited neutralizing antibodies. Cell Rep (2016) 16(9):2327-38. doi:10.1016/j.celrep.2016.07.074

89. Georgiev IS, Joyce MG, Yang Y, Sastry M, Zhang B, Baxa U, et al. Single-chain soluble BG505.SOSIP gp140 trimers as structural and antigenic mimics of mature closed HIV-1 Env. J Virol (2015) 89(10):5318-29. doi:10.1128/ JVI.03451-14

90. Sharma SK, de Val N, Bale S, Guenaga J, Tran K, Feng Y, et al. Cleavage independent HIV-1 Env trimers engineered as soluble native spike mimetics for vaccine design. Cell Rep (2015) 11(4):539-50. doi:10.1016/j. celrep.2015.03.047

91. Sanders RW, Derking R, Cupo A, Julien JP, Yasmeen A, de Val N, et al. A next-generation cleaved, soluble HIV-1 Env trimer, BG505 SOSIP.664 gp140, expresses multiple epitopes for broadly neutralizing but not non-neutralizing antibodies. PLoS Pathog (2013) 9(9):e1003618. doi:10.1371/journal. ppat. 1003618

92. Julien JP, Cupo A, Sok D, Stanfield RL, Lyumkis D, Deller MC, et al. Crystal structure of a soluble cleaved HIV-1 envelope trimer. Science (2013) 342(6165):1477-83. doi:10.1126/science.1245625

93. Stewart-Jones GB, Soto C, Lemmin T, Chuang GY, Druz A, Kong R, et al. Trimeric HIV-1-Env structures define glycan shields from clades A, B, and G. Cell (2016) 165(4):813-26. doi:10.1016/j.cell.2016.04.010

94. Guenaga J, Garces F, de Val N, Stanfield RL, Dubrovskaya V, Higgins B, et al. Glycine substitution at helix-to-coil transitions facilitates the structural determination of a stabilized subtype C HIV envelope glycoprotein. Immunity (2017) 46(5):792-803.e3. doi:10.1016/j.immuni.2017.04.014

95. Martinez-Murillo P, Tran K, Guenaga J, Lindgren G, Àdori M, Feng Y, et al. Particulate array of well-ordered HIV Clade C Env trimers elicits neutralizing antibodies that display a unique V2 cap approach. Immunity (2017) 46(5):804-17.e3. doi:10.1016/j.immuni.2017.04.021

96. Hu JK, Crampton JC, Cupo A, Ketas T, van Gils MJ, Sliepen K, et al. Murine antibody responses to cleaved soluble HIV-1 envelope trimers are highly restricted in specificity. J Virol (2015) 89(20):10383-98. doi:10.1128/ JVI.01653-15

Conflict of Interest Statement: The authors declare that the research was conducted in the absence of any commercial or financial relationships that could be construed as a potential conflict of interest.

Copyright (c) 2017 Soldemo and Karlsson Hedestam. This is an open-access article distributed under the terms of the Creative Commons Attribution License (CC BY). The use, distribution or reproduction in other forums is permitted, provided the original author(s) or licensor are credited and that the original publication in this journal is cited, in accordance with accepted academic practice. No use, distribution or reproduction is permitted which does not comply with these terms. 